\title{
Dental prosthetic treatment needs in Mexican elders: Influence of socioeconomic position
}

\section{Potrzeby leczenia protetycznego u starszych Meksykanów - wpływ czynnika socjoekonomicznego}

\author{
Horacio Islas-Granillo, ${ }^{1, A-F}$, Socorro Aida Borges-Yañez ${ }^{2, A-F}$, Carlo Eduardo Medina-Solis ${ }^{1, A-F}$, Sonia Márquez-Rodríguez ${ }^{1,(-F}$, \\ Salvador Eduardo Lucas-Rincón ${ }^{3,-}{ }^{3}$, Miguel Ángel Fernández-Barrera', ${ }^{1,(-F}$, Arturo Ascencio-Villagrán ${ }^{1, C-F}$, Miriam Alejandra Veras-Hernández,,-F \\ ${ }^{1}$ Academic Area of Dentistry of Health Sciences Institute, Autonomous University of Hidalgo State, Pachuca, Mexico \\ ${ }^{2}$ DEPel Faculty of Dentistry of National Autonomous University of Mexico, Ciudad de Mexico, Mexico \\ ${ }^{3}$ Advanced Studies and Research Center in Dentistry "Dr. Keisaburo Miyata" of School of Dentistry, Autonomous University of the State of Mexico, Toluca, Mexico \\ A - research concept and design; $B$ - collection and/or assembly of data; $C$ - data analysis and interpretation; \\ $D$ - writing the article; $E$ - critical revision of the article; $F$ - final approval of the article
}

Address for correspondence

Carlo Eduardo Medina Solís

E-mail: cemedinas@yahoo.com

Funding sources

None declared

Conflict of interest

None declared

Received on September 1, 2017

Reviewed on September 6, 2017

Accepted on September 27, 2017

DOI

$10.17219 / \mathrm{dmp} / 78029$

Copyright

○ 2017 by Wroclaw Medical University

and Polish Dental Society

This is an article distributed under the terms of the

Creative Commons Attribution Non-Commercial License

(http://creativecommons.org/licenses/by-nc-nd/4.0/)

\begin{abstract}
Background. According to the Global Burden of Oral Conditions in 1990-2010 report, oral diseases are highly prevalent. Tooth loss is also a prevalent oral condition. Poor oral health compromises healthy aging, as it impacts an older person's quality of life and general health.

Objectives. The aim of this study was to determine the influence of various indicators of socioeconomic position on dental prosthetic treatment needs in Mexican adults aged 60 and over.
\end{abstract}

Material and methods. A cross-sectional study was carried out in older adults aged 60 and over who were residents in 2 nursing homes and a senior citizen club in the city of Pachuca, Mexico. By means of a clinical exploration, tooth loss and dental rehabilitation status were determined, which was our dependent variable. This was dichotomized as $0=$ subjects with loss of teeth but rehabilitated with a dental prosthesis; and $1=$ subjects with loss of teeth and in need of dental prosthesis treatment. Using a questionnaire, a series of sociodemographic, socioeconomic, behavioral and health variables were collected. A statistical analysis was performed in Stata 13 using the $x^{2}$ test.

Results. The mean age was $79.03 \pm 9.81$ years. Most of the subjects included in the study were women (68.8\%). The prevalence of dental prosthetic treatment needs was $53.6 \%$. Higher dental prosthetic treatment requirements $(p<0.05)$ were observed among subjects who did not have access to health insurance, in those with education less than elementary, among those who attended a publicly funded nursing home and those who did not have the social benefit of being retired/pensioned.

Conclusions. This sample of elderly people presented high dental prosthetic treatment needs for more than half of the subjects studied. It was observed that the variables indicating socioeconomic position had a great impact on the dental prosthetic needs, which represents the existence of inequalities in oral health.

Key words: elderly, oral health, tooth loss, health needs

Słowa kluczowe: osoby starsze, zdrowie jamy ustnej, utrata zębów, potrzeby zdrowotne 
The main oral health problems around the world continue to be dental caries and periodontal diseases. Dental biofilm is an important biological determinant common for the development of both diseases. The diseases share common risk factors and social determinants that are essential for their prevention and control. According to the Global Burden of Oral Conditions in 1990-2010 report, oral diseases are highly prevalent, collectively affecting about 3.9 billion people around the world, thus representing major oral public health problems. In that study, the most common disease of all conditions evaluated, and with the highest burden of disease globally was untreated dental caries in the permanent dentition, affecting 35\% of people in all age groups, while severe periodontitis was the $6^{\text {th }}$ most prevalent condition, affecting $11 \%$ overall. ${ }^{1-4}$ As chronic diseases are cumulative throughout life, once they occur, their manifestation persists throughout life, so the results are more likely to be observed among the elderly. Its main consequence is tooth loss, which is also a prevalent oral condition; in fact, severe tooth loss is the $36^{\text {th }}$ most prevalent condition, with an overall estimate of $2 \% .^{5}$

In recent years, progress in the prevention and treatment of dental caries and periodontal diseases has resulted in better oral health and greater retention of teeth in the adult population. However, the aging of the population and the growing expectations of a good quality of life related to oral health at an advanced age pose enormous challenges for society in general, as well as for clinical care and the health systems in particular; since there are several demands and health needs specific to older adults that need to be covered. ${ }^{6,7}$ To achieve this, it is necessary to have highly qualified economic, technological and human resources. ${ }^{8}$ Therefore, due to the increasing number of older adults, the need to carry out epidemiological studies on oral health centered on this population has arisen. ${ }^{9}$ One of the first steps in planning dental services is to compile up-to-date information on the prevalence of oral diseases. With this information, it is possible to evaluate future treatment needs and service demands. At the same time, estimating the need for treatment is an essential requirement in planning oral health care. With regard to tooth loss, standard treatment involves the placement of prosthetic devices such as total or partial prosthesis. ${ }^{10}$

According to recent research, there is strong evidence of an association of low socioeconomic position with an increased risk of having dental caries experience and a higher prevalence of periodontitis. This is typical of the phenomenon known as "socioeconomic inequalities in health", which refer to the different health-related opportunities and resources that people of different social classes have. The most disadvantaged groups present a worse state of health than their better-positioned counterparts, a situation which has its origin in the inequalities of the economic and social policies that exist in society. ${ }^{11}$ In this regard, studies carried out in several countries around the world, both developed and developing, reveal the existence of so- cioeconomic inequalities in various aspects of health, observing that the socioeconomically disadvantaged population is the one with the lowest levels of health. ${ }^{12}$

Several studies on dental prosthetic needs have been conducted in several countries, principally in developing ones. For example, in India, Bhardwaj et al. found that in a sample of adults aged $18-58$ years, $33.2 \%$ had prosthetic requirements and that these were associated with their socioeconomic position. ${ }^{13}$ Another study reports dental prosthetic needs in $81.2 \%$ of people aged 60 and over. ${ }^{14}$ In Saudi Arabia, Peeran et al. performed a study in adults aged 35-74 years and observed that about $56 \%$ of the participants had dental prosthetic needs. ${ }^{15}$ On the other hand, in Thailand, prosthetic needs reach $60 \%$ in subjects aged $60-75$ years. ${ }^{16}$ The determination of prosthetic needs in Mexico is a little-explored subject so the objective of the present study was to determine the influence of various indicators of the socioeconomic position on prosthetic needs in elderly Mexicans of 60 years and over.

\section{Material and methods}

\section{Design and study sample}

A cross-sectional, observational, analytical study was performed on subjects aged 60 years and over in 2 nursing homes and a club for the elderly located in the city of Pachuca, Hidalgo, Mexico, where several oral health indicators were measured. Part of the methodology has been previously published, covering various oral health topics. ${ }^{17-21}$ Once the appropriate permits had been obtained, the subjects were invited to participate in the study. They were informed of the objectives of the investigation, the confidentiality of data management, and instructed that they could stop participating at any time. The inclusion criteria were: 1) people who wished to participate in the research and they or their relatives authorized it; 2) people who were enrolled in the aforementioned groups; and 3) have lost at least 1 tooth, whereas the exclusion criteria were: 1) they had any auditory or language defects that made the interview difficult; and 2) with a physical disability that prevented the oral examination. No sampling was performed; the participants were all volunteers who agreed to participate in the study. The total sample at baseline consisted of 151 subjects. Out of these, 13 refused to take part in the study or were disqualified according to the criteria so in the end 138 subjects were studied.

\section{Variables and data collection}

The dependent variable was formed by the state of tooth loss and the use of any dental prosthesis, which was dichotomized as: $0=$ subjects with loss of teeth, but rehabilitated with a dental prosthesis; and 1 = subjects with 
loss of teeth and in need of a dental prosthesis (not rehabilitated). Questionnaires were used to collect information on sociodemographic variables such as age, sex, and marital status as well as socioeconomic variables such as type of nursing home, health insurance, schooling and retirement/pension social benefits; in addition to various behavioral and exposures factors such as frequency of dental brushing and presence of chronic diseases (multimorbidity).

To determine the status of the dentition (missing teeth) and the needs for dental prosthetics, a clinical examination was performed on each of the subjects. Clinical examinations were performed by a single examiner who had been previously standardized and trained in the criteria, using a flat dental mirror and a WHO-type periodontal probe, with the patient comfortably seated in a room with an artificial light.

\section{Analysis of data}

The information collected from the questionnaires and the clinical examination was analyzed in Stata $13.0^{\circledR}$. First, a descriptive analysis of the sample was carried out, reporting measures of central tendency and dispersion for the quantitative variables as well as the frequency and percentages for the qualitative variables. Subsequently, a bivariate analysis was performed to determine the existence of differences in the distribution of dental prosthetic needs and independent variables using the $\chi^{2}$ test with the level of significance $\mathrm{p}<0.05$.

\section{Ethical Considerations}

The completion of this study was complied with the specifications of the general health law in research of Mexico and with the scientific principles of Helsinki. All individuals signed an informed consent form. The protocol was approved by the Postgraduate and Research Unit of the Academic Area of Dentistry of the Autonomous University of the State of Hidalgo (UAEH-DI-ICSAODO-CF-008).

\section{Results}

The results of the descriptive analysis are shown in Table 1 . The mean age was $79.03 \pm 9.81$. Most subjects included were women (68.8\%). Almost half (44.9\%) of them were divorced or widowed at the time of the survey. More than half (53.6\%) had no access to health insurance. Out of the elderly people in our sample, $64.5 \%$ had failed to complete even elementary schooling. The majority (60.1\%) attended a publicly funded nursing home. Only 1 in 5 had the social benefit of being retired/pensioned. $27.5 \%$ of subjects had multi-morbidity. Just over a half reported brushing their teeth at least once a day.
Table 1. Description of the characteristics of subjects included in the study

\begin{tabular}{|c|c|c|}
\hline Variables & Frequency & Percentage \\
\hline $\begin{array}{l}\text { Sex } \\
\text { male } \\
\text { female }\end{array}$ & $\begin{array}{l}43 \\
95\end{array}$ & $\begin{array}{l}31.2 \\
68.8\end{array}$ \\
\hline $\begin{array}{l}\text { Age } \\
60 \text { to } 74 \text { years } \\
75 \text { to } 84 \text { years } \\
85 \text { and more }\end{array}$ & $\begin{array}{l}47 \\
46 \\
45\end{array}$ & $\begin{array}{l}34.1 \\
33.3 \\
32.6\end{array}$ \\
\hline $\begin{array}{l}\text { Marital status } \\
\text { single } \\
\text { in a relationship } \\
\text { divorced/widowed }\end{array}$ & $\begin{array}{l}52 \\
24 \\
62\end{array}$ & $\begin{array}{l}37.7 \\
17.4 \\
44.9\end{array}$ \\
\hline $\begin{array}{l}\text { Type of location } \\
\text { publicly funded } \\
\text { private } \\
\text { adult day center }\end{array}$ & $\begin{array}{l}83 \\
31 \\
24\end{array}$ & $\begin{array}{l}60.1 \\
22.5 \\
17.4\end{array}$ \\
\hline $\begin{array}{l}\text { Health insurance } \\
\text { yes } \\
\text { no }\end{array}$ & $\begin{array}{l}64 \\
74\end{array}$ & $\begin{array}{l}46.4 \\
53.6\end{array}$ \\
\hline $\begin{array}{l}\text { Schooling } \\
\text { elementary school and more } \\
\text { less than elementary school }\end{array}$ & $\begin{array}{l}49 \\
89\end{array}$ & $\begin{array}{l}35.5 \\
64.5\end{array}$ \\
\hline $\begin{array}{l}\text { Pension/retirement } \\
\text { no benefit } \\
\text { with benefit }\end{array}$ & $\begin{array}{r}104 \\
34\end{array}$ & $\begin{array}{l}75.4 \\
24.6\end{array}$ \\
\hline $\begin{array}{l}\text { Multi-morbidity } \\
0 \text { or } 1 \text { disease } \\
2 \text { or more }\end{array}$ & $\begin{array}{r}100 \\
38\end{array}$ & $\begin{array}{l}72.5 \\
27.5\end{array}$ \\
\hline $\begin{array}{l}\text { Tooth brushing frequency } \\
\text { less than once/day } \\
\text { at least once or more times/day }\end{array}$ & $\begin{array}{l}65 \\
73\end{array}$ & $\begin{array}{l}47.1 \\
52.9\end{array}$ \\
\hline
\end{tabular}

Table 2 shows the description of tooth loss (at least 1) and the state of oral rehabilitation. With this data we determined that the prevalence of dental prosthetic needs was $53.6 \%$.

Table 3 shows the results of the bivariate analysis. The variables that show significant results were related to the socioeconomic position. Thus, greater dental prosthetic needs were observed when the subject did not have access to health insurance $(68.9 \%$ vs $35.9 \%)$ than when they did $(\mathrm{p}<0.001)$. Likewise, the percentage of dental prosthetic needs was higher in those with incomplete elementary schooling $(64.0 \%$ vs $34.7 \%)$ than in those with more extensive education $(\mathrm{p}<0.01)$. Subjects attending a publicly funded nursing home had higher dental prosthetic needs Table 2. Description of tooth loss and state of dental rehabilitation in elderly Mexicans

\begin{tabular}{|l|c|c|}
\hline \multicolumn{1}{|c|}{ Variables } & Frequency & Percentage \\
\hline Dental status & & \\
edentulous with prosthesis & 27 & 19.6 \\
lost teeth with prosthesis & 37 & 26.8 \\
edentulous without prosthesis & 27 & 19.6 \\
lost teeth $(<21)$ without prosthesis & 33 & 23.9 \\
lost teeth $(>20)$ without prosthesis & 14 & 10.1 \\
Dental prosthetic needs & & \\
no prosthetic needs & 64 & 46.4 \\
with prosthetic needs* & 74 & 53.6 \\
\hline
\end{tabular}

* - It refers to subjects who had at least 1 missing tooth and were not rehabilitated with any type of dental prosthesis. 
Table 3. Bivariate analysis of dental prosthetic needs and independent variables

\begin{tabular}{|c|c|c|c|}
\hline \multirow[b]{2}{*}{ Varibles } & \multicolumn{2}{|c|}{ Dental prosthetic needs } & \multirow[b]{2}{*}{ p-value } \\
\hline & $\begin{array}{l}\text { with } \\
\text { need }\end{array}$ & $\begin{array}{l}\text { without } \\
\text { need }\end{array}$ & \\
\hline $\begin{array}{l}\text { Sex } \\
\text { male } \\
\text { female }\end{array}$ & $\begin{array}{l}15(34.9) \\
49(51.6)\end{array}$ & $\begin{array}{l}28(65.1) \\
46(48.4)\end{array}$ & $\begin{array}{c}x^{2}=3.3178 \\
p=0.069\end{array}$ \\
\hline $\begin{array}{l}\text { Age } \\
60 \text { to } 74 \text { years } \\
75 \text { to } 84 \text { years } \\
85 \text { and more }\end{array}$ & $\begin{array}{l}23(48.9) \\
19(41.3) \\
22(48.9)\end{array}$ & $\begin{array}{l}24(51.1) \\
27(58.7) \\
23(51.1)\end{array}$ & $\begin{array}{c}x^{2}=0.7139 \\
p=0.700\end{array}$ \\
\hline $\begin{array}{l}\text { Marital status } \\
\text { single } \\
\text { in a relationship } \\
\text { divorced/widowed }\end{array}$ & $\begin{array}{l}23(44.2) \\
11(45.8) \\
30(48.4)\end{array}$ & $\begin{array}{l}29(55.8) \\
13(54.2) \\
32(51.6)\end{array}$ & $\begin{array}{c}x^{2}=0.1999 \\
p=0.905\end{array}$ \\
\hline $\begin{array}{l}\text { Type of location } \\
\text { publicly funded } \\
\text { private } \\
\text { adult day center }\end{array}$ & $\begin{array}{l}30(36.1) \\
13(41.9) \\
21(87.5)\end{array}$ & $\begin{array}{r}53(63.9) \\
18(58.1) \\
3(12.5)\end{array}$ & $\begin{array}{c}x^{2}=20.0606 \\
p=0.000\end{array}$ \\
\hline $\begin{array}{l}\text { Health insurance } \\
\text { yes } \\
\text { no }\end{array}$ & $\begin{array}{l}41(64.1) \\
23(31.1)\end{array}$ & $\begin{array}{l}23(35.9) \\
51(68.9)\end{array}$ & $\begin{array}{c}x^{2}=15.0113 \\
p=0.000\end{array}$ \\
\hline $\begin{array}{l}\text { Schooling } \\
\text { elementary school and more } \\
\text { less than elementary school }\end{array}$ & $\begin{array}{l}32(65.3) \\
32(36.0)\end{array}$ & $\begin{array}{l}17(34.7) \\
57(64.0)\end{array}$ & $\begin{array}{c}x^{2}=10.9472 \\
p=0.001\end{array}$ \\
\hline $\begin{array}{l}\text { Pension/retirement } \\
\text { no benefit } \\
\text { with benefit }\end{array}$ & $\begin{array}{l}39(37.5) \\
25(73.5)\end{array}$ & $\begin{array}{r}65(62.5) \\
9(26.5)\end{array}$ & $\begin{array}{c}x^{2}=13.3750 \\
p=0.000\end{array}$ \\
\hline $\begin{array}{l}\text { Multi-morbidity } \\
0 \text { or } 1 \text { disease } \\
2 \text { or more }\end{array}$ & $\begin{array}{l}45(45.0) \\
19(50.0)\end{array}$ & $\begin{array}{l}55(55.0) \\
19(50.0)\end{array}$ & $\begin{array}{c}x^{2}=0.2768 \\
p=0.599\end{array}$ \\
\hline $\begin{array}{l}\text { Tooth brushing frequency } \\
\text { less than once/day } \\
\text { At least once or more times/day }\end{array}$ & $\begin{array}{l}29(44.6) \\
35(47.9)\end{array}$ & $\begin{array}{l}36(55.4) \\
38(52.1)\end{array}$ & $\begin{array}{c}x^{2}=0.1533 \\
p=0.695\end{array}$ \\
\hline
\end{tabular}

(63.9\%) than those who attended a private nursing home (58.1\%) or a club for the elderly $(12.5 \%)$ ( $\mathrm{p}<0.001)$. Finally, if they did not have the social benefit of being retired/pensioned, they had a higher prevalence of dental prosthetic needs $(62.5 \%$ vs $26.5 \%)$ than those who were retired/pensioned $(\mathrm{p}<0.001)$.

\section{Discussion}

The results of this study in a sample of elderly Mexicans showed a high need for dental prosthetic care (53.6\%), which was associated with various indicators of socioeconomic position. In other studies, a prevalence ranging from 33.2 to $81.2 \%$ has been observed, depending on the population group studied. ${ }^{13-16}$ Although there have been substantial improvements in the oral health of populations in several countries, different dental problems persist worldwide. The burden of oral diseases is particularly high in socioeconomically disadvantaged populations, which can be observed in both developing and developed countries. Oral diseases such as dental caries, periodontopathies, tooth loss, oral mucosal lesions and oropharyngeal cancers, oral diseases related to human immunodeficiency virus/acquired immunodeficiency syndrome (HIV/AIDS) and dental trauma injuries are important public health problems worldwide, and it has been shown that poor oral health has profound effects on health and quality of life. ${ }^{22}$ Despite this scenario, the World Health Organization has demonstrated the existence of limited availability or inaccessibility of oral health services, which makes its utilization rates particularly low among some vulnerable groups of the population. Also, it is estimated that in high-income countries the curative dental care consumes between 5 and $10 \%$ of public health expenditure. ${ }^{23}$

The impact of the socioeconomic position on different oral health indicators has been amply demonstrated. ${ }^{7}$ Similarly, studies in India have also revealed that dental prosthesis requirements are increasing among subjects with the lowest socioeconomic position. ${ }^{13}$ In this sense, we find 4 variables that refer to the socioeconomic position (health insurance, schooling, type of nursing home and retiree/pensioner). The exact mechanism by which the socioeconomic position of the individuals or the context in which they live is associated health effects is not very clear, because the socioeconomic position is a multidimensional construct. ${ }^{12}$ Some authors have proposed several mechanisms to try to explain this association. For example, a molecular basis such as the modulation of the immune system response via infections. ${ }^{24}$ Other authors mention the influence of the various exposures of the community in which the subjects live. For example, in neighborhoods characterized by low educational level, health outcomes are modified, even independently of the level of schooling and social class. A combination of community and individual measures is also possible. ${ }^{25}$ Other researchers say that health can be affected by unhealthy lifestyles and behaviors as well as by access to poor quality services for people with poor socioeconomic status. ${ }^{26}$

Social pressure to maintain esthetics and function may be the driving force that influences subjects of better socioeconomic position to replace their missing teeth. In addition to this, a more positive attitude toward dental care, awareness and the cost of dental treatment could also be an important factor determining a person's dental prosthetic condition. ${ }^{13}$ In this sense, in Mexico, it has been consistently observed that the subjects with the best socioeconomic position are also those who use dental health services more than their counterparts with the lowest socioeconomic position, both preventive and curative services. ${ }^{27}$

In Mexico, oral diseases such as dental caries and periodontal diseases remain the main public oral health problems in the general population, and are the most common reason for the extraction of teeth in the adult population. ${ }^{28}$ Consequently, the prevention and control of these diseases as well as the prevention of tooth loss is a commitment of oral health workers in the population and in individuals. Prosthetic rehabilitation with conventional complete dentures or with removable dentures results in an overall upgrade in patients' quality of life. ${ }^{29}$ 


\section{Conclusions}

Based on the results obtained in the study, we can conclude that this sample of elderly people presented high dental prosthetic needs, in more than half of the subjects studied. Also, it was observed that variables indicating the socioeconomic position had a great impact on dental prosthetic needs, which represents the existence of inequalities in oral health. It is necessary to eliminate the barriers (such as economic, access, geographical) that prevent people with a worse socioeconomic position to rehabilitate their dental status, and thus reduce oral health gaps between different levels of socioeconomic position.

\section{References}

1. Sulewska M, Pietruski J, Sulima E, et al. Periodontal status of Białystok citizens aged 65-74 years: A pilot study. Dent Med Probl. 2017;54:173-178.

2. Marcenes W, Kassebaum NJ, Bernabé E, et al. Global burden of oral conditions in 1990-2010: A systematic analysis. J Dent Res. 2013;92:592-597.

3. Kassebaum NJ, Bernabé E, Dahiya M, Bhandari B, Murray CJ, Marcenes W. Global burden of severe periodontitis in 1990-2010: A systematic review and meta-regression. J Dent Res. 2014;93:1045-1053.

4. Kassebaum NJ, Bernabé E, Dahiya M, Bhandari B, Murray CJ, Marcenes W. Global burden of untreated caries: A systematic review and metaregression. J Dent Res. 2015;94:650-658.

5. Kassebaum NJ, Bernabé E, Dahiya M, Bhandari B, Murray CJ, Marcenes W. Global Burden of Severe Tooth Loss: A Systematic Review and meta-analysis. J Dent Res. 2014;93(Suppl. 7):20S-28S

6. Tonetti MS, Bottenberg P, Conrads G, et al. Dental caries and periodontal diseases in the ageing population: Call to action to protect and enhance oral health and well-being as an essential component of healthy ageing - Consensus report of group 4 of the joint EFP/ ORCA workshop on the boundaries between caries and periodontal diseases. J Clin Periodontol. 2017:44(Suppl. 18):135-144.

7. Łysek R, Polak M, Szafraniec K, et al. Socioeconomic status, health behaviours and oral health in adult urban population of Krakow. Dent Med Probl. 2016;53:66-77.

8. Sánchez-García S, Juárez-Cedillo T, Gallegos-Carrillo K, Gallo J, Wagner FA, García-Peña C. Frequency of depressive symptoms among older adults in Mexico City. Salud Ment. 2012;35:71-77 [in Spanish].

9. Renvert S, Persson RE, Persson GR. Tooth loss and periodontitis in older individuals: Results from the Swedish National Study on Aging and Care. J Periodontol. 2013;84:1134-1144.

10. Shah VR, Shah DN, Parmar $\mathrm{CH}$. Prosthetic status and prosthetic need among the patients attending various dental institutes of Ahmedabad and Gandhinagar district, Gujarat. J Indian Prosthodont Soc. 2012;12:161-167.

11. Whitehead M, Dahlgren G. Concepts and principles for tackling social inequities in health. Copenhagen: World Health Organization Regional Office for Europe; 2007.

12. Laaksonen $M$, Rahkonen $\mathrm{O}$, Martikainen $\mathrm{P}$, Lahelma E. Socioeconomic position and self-rated health: The contribution of childhood socioeconomic circumstances, adult socioeconomic status, and material resources. Am J Public Health. 2005;95:1403-1409.

13. Bhardwaj VK, Veeresha KL, Sharma KR. Dental prosthetic status, prosthetic needs in relation to socioeconomic status of the state government employees in Shimla city (Himachal Pradesh) - A cross sectional study. J Int Soc Prev Community Dent. 2011;1:52-56.

14. Deogade SC, Vinay S, Naidu S. Dental prosthetic status and prosthetic needs of institutionalised elderly population in old-age homes of Jabalpur city, Madhya Pradesh, India. J Indian Prosthodont Soc. 2013;13:587-592.

15. Peeran SA, Al Sanabani F, AL-Makramani BM, Elamin El. Dental prosthetic status and treatment needs of adult population in Jizan, Saudi Arabia: A survey report. Eur J Dent. 2016;10:459-463.
16. Srisilapanan P, Sheiham A. Assessing the difference between sociodental and normative approaches to assessing prosthetic dental treatment needs in dentate older people. Gerodontol. 2001;18:25-34.

17. Islas-Granillo H, Borges-Yáñez A, Fernández-Barrera MA, et al. Relationship of hyposalivation and xerostomia in Mexican elderly with socioeconomic, sociodemographic and dental factors. Sci Rep. 2017;6:40686.

18. Domínguez-Moreno DC, Islas-Granillo H, Medina-Solís CE. Severity and extent of periodontitis in the elderly of three asylum groups in Pachuca. Boletín Científico Educación y Salud. 2016;5:1-8 [in Spanish].

19. Islas-Granillo H, Borges-Yañez SA, Medina-Solís CE, et al. Tooth loss experience and associated variables among adult Mexicans 60 years and older. PR Health Sci J. 2016;35:88-92.

20. Islas-Granillo $H$, Medina-Solís $C E$, Navarrete-Hernández JJ, et al. Prevalence of functional dentition in Mexican elderly. Rev Clin Periodoncia Implantol Rehabil Oral. 2015;8:150-156 [in Spanish].

21. Islas-Granillo H, Borges-Yañez SA, Medina-Solís CE, et al. Salivary parameters (salivary flow, $\mathrm{pH}$ and buffering capacity) in stimulated saliva of Mexican elders 60 years old and older. West Indian Med J. 2014;63:758-765.

22. Petersen PE, Bourgeois D, Ogawa H, Estupinan-Day S, Ndiaye C. The global burden of oral diseases and risks to oral health. Bull World Health Organ. 2005;83:661-669.

23. WHO. Oral health. Informative note 318. 2012: http://www.who.int/ mediacentre/factsheets/fs318/es/ Updated September 18, 2016 [in Spanish].

24. Dowd JB, Haan MN, Blythe L, Moore K, Aiello AE. Socioeconomic gradients in immune response to latent infection. Am J Epidemiol. 2008;167:112-120.

25. Basagaña $X$, Sunyer J, Kogevinas $M$, et al. Socioeconomic status and asthma prevalence in young adults: The European Community Respiratory Health Survey. Am J Epidemiol. 2004;160:178-188.

26. Jepsen S, Blanco J, Buchalla W, et al. Prevention and control of dental caries and periodontal diseases at individual and population level: Consensus report of group 3 of joint EFP/ORCA workshop on the boundaries between caries and periodontal diseases. J Clin Periodontol. 2017;44(Suppl. 18):85-93.

27. Jiménez-Gayosso SI, Medina-Solís CE, Lara-Carrillo E, et al. Socioeconomic inequalities in oral health service utilization any time in their lives for Mexican schoolchildren from 6 to 12 years old. Gac Med Mex. 2015;151:27-33 [in Spanish].

28. Medina-Solís CE, Pontigo-Loyola AP, Pérez-Campos E, et al. Principal reasons for extraction of permanent tooth in a sample of Mexicans adults. Rev Invest Clin. 2013;65:141-149 [in Spanish].

29. Kołciuk L, Godlewski T. Oral health-related quality of life of patients using removable dentures - review of literature. Dent Med Probl. 2015;52:222-226. 
